The symmetries of his achievement are irresistible. Quintessential early works such as - the overtures Aotearoa, Festival and Drysdale and the cantata Prodigal Country were part of the centennial celebrations of 1940 when Douglas Lilburn was a youthful twenty-five year old. Today, in 1990, we celebrate the composer at seventy-five years and an anniversary of 150 years of nationhood.

The works of the intervening fifty years are all about that 'something very strange', - 'the vivid night smell of the bush country' and the challenge to others to make the New Zealand journeys that are their own version of a 'hair-raising' experience in the Marlborough Sounds. Within this exhibition the maps and routes of this musical traveller are laid out for us all to experience and understand. This is an appropriate and timely tribute to the work of this great New Zealand artist for which we owe curator Jill Palmer a resonant accolade.

Douglas Lilburn's journey is part of a larger flow. A flow expertly woven and interpreted by curator John Mansfield Thomson to whom I offer congratulations and thanks for the benefits of his wisdom and knowledge in finding and making these pathways.

Music is the province and property of all human kind. Of people from all walks of life, backgrounds, origins and beliefs. It is simultaneously their servant, their reflection and their release. And each place and each time has its own music. And each music has the unique ability to translate across time, borders and barriers whatever they may be - social, physical or intellectual.

On this journey backwards through time we will discover the music that was brought to these shores by the early settlers; the music that was here long before they arrived; the objects that were and are a part of music here; and the uses and functions of music in the life of New Zealanders in its myriad manifestations.

And the music we will discover is a part of the living tradition of music in New Zealand. Music, almost more than any of the arts, builds and grows on what has gone before. Be it conscious or unconscious the sights and sounds of this exhibition have, through the passage of time each contributed to the musics of 1990 - our music of the concert hall, the recital chamber, the dance hall, school room, pub, party, after-match function. They are all part of it - I urge you to celebrate it, enjoy it and above all embrace it.

I am delighted to declare this exhibition open.

\title{
An operatic tradition
}

\section{ADRIENNE SIMPSON in conversation with J.M.THOMSON}

Adrienne Simpson's recent seminar at the Stout Centre on the Simonsen Opera Company gave striking evidence of the popularity of opera in 19th-century New Zealand, not only in cities but in the many small towns which the travelling companies included in their schedules. Today, opera is the cinderella of the arts, rebuilding in regional form after the fateful decision of the $Q E I I$ to withdraw national funding from the New Zealand Opera Company and its successor, the New Zealand National Opera. In this interview, J.M. Thomson asks Adrienne Simpson why opera is such a potent force in a country where, in the view of today's policy makers, it is often considered irrelevant to cultural aspirations. In other words, how meaningful is opera to present-day New Zealand?

Any art form enjoyed by so many New Zealanders has to be relevant. Opera is one of the few growth forms in New Zealand. More and more people are attending opera, wanting to participate in it and, steadily, more and more professional performances are being put on. A Hillary Commission report carried out a couple of years ago showed that more New Zealanders participate in and enjoy the arts than take part in or watch rugby. This country produces fine operatic singers with much the same prodigality as it produces All Blacks. In proportion to its 
size there are more singers from New Zealand involved in international operatic activities than from there are many countries which would be considered centres of operatic tradition. I recall John Matheson (a New Zealander who made an international career as a conductor of opera) pointing out that Italy, today, had only one operatic superstar - Luciano Pavarotti - whereas New Zealand had two, Kiri te Kanawa and Donald McIntyre.

In the 1990 Wellington International Festival of the Arts Wagner's Meistersinger established new standards: it also highlighted the fact that despite such operatic skills New Zealand singers, technicians, etc had only a limited base in their own country from which to operate. The whole production, if it is not to be considered a solitary triumph, simply underlined the dilemma of the New Zealand singer seeking a career in opera.

It is true that most New Zealand singers have to work abroad: in Europe, America and particularly Australia. The Australian Opera, based in Sydney, is now one of the great companies of the world. It is heavily reliant on New Zealand talent as are other companies such as the Victorian State Opera and the Lyric Opera of Queensland. As to Die Miestersinger, I think it came at a very approriate time. It caught the upsurge of interest and gave it a great deal of extra impetus. It also proved, to people who had perhaps never been to opera before, that it is not daunting - that the myth about opera being difficult, or elitist, was simply a myth.

Any living operatic tradition is based on its composers as Benjamin Britten so readily proved in England, and as Janacek earlier showed in Czechoslovakia. What signs are there in New Zealand that there might be enough interest in writing for opera to sustain a native New Zealand tradition?

I can think of several New Zealand composers writing operas, but most of them have great difficulty in achieving performances. Because of the years lost during the time when opera struggled to re-establish itself, the New Zealand public is not yet ready for contemporary New Zealand operas. Financially, the companies are not yet able to absorb the consequent losses they would suffer. The answer is, of course, some form of subsidy, but there is little evidence that financial encouragement towards the production of New Zealand opera will be forthcoming.

To take one example: Chris Blake has been writing an opera for Mercury in Auckland. Entitled A Bitter Calm, the work is based on the story of the young Maori, Maketu, who killed the family of his employer and was himself sentenced to be hung. It is an important work, focussing on cross-cultural relationships and attitudes, and written by perhaps the most theatrically knowledgeable of all our contemporary composers. However, Mercury have been unable to find any extra funding to enable them to mount the work.

Despite the discouragements, many fine creative talents are involving themselves in operatic work. Witi Ihimaera, for example has written two opera libretti, one for Ross Harris and another for William Southgate.

This brings forward the Maori dimension in opera. I noticed recently how Ranginui Walker revealed in the Dominion Sunday Times of 16 September that besides Beethoven, he loved opera. What comment would you make on this?

Maori music is above all a vocal art, not an instrumental one. It's not for nothing that the talents of the Maori have been likened to those of the Welsh who're spontaneous in their enjoyment of anything vocal. The colour, the drama, and the emotional aspects of opera have always been very likely to appeal strongly to any people who have a lively vocal and visual element in their culture. It is not at all surprising that two of New Zealand's greatest singers have been Maori, Inia Te Wiata and Kiri Te Kanawa.

\section{Do the roots of the New Zealand operatic tradition go back to the nineteenth century?}

Oh yes, it's a continuing tradition. The sad thing is that because people are not taught the musical history of New Zealand, almost nobody is aware of that tradition. Professional opera was first produced in New Zealand in 1864, and opera was exceedingly popular thereafter, with 
professional companies travelling regularly through the country, visiting not only the main centres but also towns which would hardly ever see professional productions today - towns like Nelson, Wanganui, New Plymouth and Napier. After the big touring companies of this century, with the top Williamson casts of 1932, there was a hiatus during the second world war. Afterwards, following tours by Italian and Australian companies, Donald Munro's New Zealand Opera Company was established in 1954, becoming professional. At the time people thought this represented the first stirrings of operatic activity in New Zealand. They'd lost touch with the continuity of what had gone before

\section{Will your forthcoming book, O'pera in New Zealand: aspects of history and performance' open up new territory?}

I believe so. It arose from a feeling that some attempt should be made to indicate the richness of the operatic tradition in New Zealand. As a preliminary step to more comprehensive books I felt there was a chance to draw on the expertise of a number of people who'd studied individual aspects in isolation, so producing a symposium that would immediately give an indication of the variety of the territory. It was originally intended to celebrate the 35 th anniversary of the New Zealand Opera Society which since it coincided with 1990, it seemed appropriate to mark in some permanent fashion. The book has grown beyond its modest first concept, but is still dedicated to the Opera Society, who have supported its publication.

The book contains sections on companies, composers, singers and supporters. Included are the stories of New Zealand's first two international prima donnas, Frances Alda and Rosina Buckman, the first of whom was a star at the New York Metropolitan by 1908, and the second of whom made her name at Covent Garden just before World War I. They were both colourful characters, but not as colourful as New Zealand's earliest operatic composer whose works reached the iniernational stage, Luscombe Searelle. And for those who have a taste for the unusual, the story of Tom Pollard and his Lilliputians, New Zealand's first indigenous opera company, made up of young children between the ages of about eight and eighteen, has to be read to be believed. The range of this book's contents will certainly surprise anyone who believes that New Zealand has no operatic past.

\section{Du you believe that a historical study of opera is a crucial part of any rounded approach to the nature of New Zaland society?}

If we don't study the kinds of things people enjoyed, we only get a partial picture of their lives. It tells us something about Julius Vogel when we know that, in his youth, he was a wildly enthusiastic amateur actor. As premier he was assiduous in patronising the Simonsens Opera Company, attending as many performances as he could manage. There are many other aspects of the effect of the travelling opera companies on New Zealand musical life. The composer, Alfred Hill was taught the cornet by William Mathias, principal cornet of the Simonsen Opera Company's orchestra, and violin by Rivers Allpress, leader of that same orchestra. When the company went away, he described himself as being "like a ship without a rudder...". Opera is far from Dr Johnson's dismissal of it as "an irrational entertainment": it can be a potent nationalistic force as with Janacek and chrystallise whole aspects of a country's musical culture as with Britten. In New Zealand it is still early days.

\section{TE TIRITI O WAITANGI : ONE TREATY AMONG OTHERS?}

\section{From conversation to conference Genesis of the 1990 Stout Centre Conference BILL RENWICK}

The 1990 Stout Conference had its genesis in a conversation Claudia Orange and I had about two years ago. I had already agreed to organise the conference. I was casting about for a theme and, given that it would be held in 1990, something associated with the Treaty seemed right. But even by 1988 discussions on the Treaty were following a well beaten track. 